
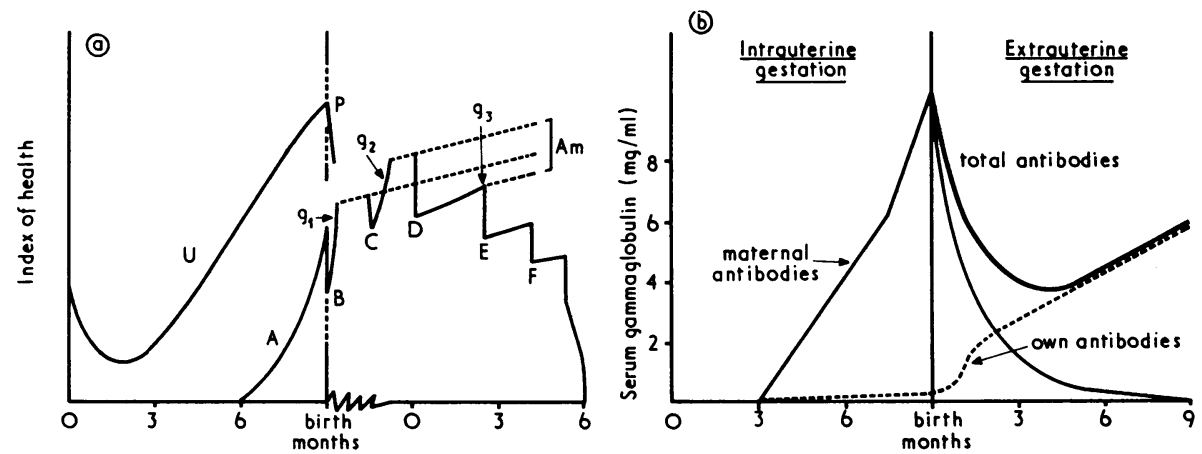

FIG. 1-Levels of health. (a) Physiological health charted without absolute units, relative to two cocoons, the uterus $(U)$ and the immediate outside world $(A-F)$. $P$ is a hypothetical loss of health at post-maturity relative to the uterus. B-F are episodes of lowered health relative to the outside world, followed by coping with challenges, the most prompt (B) being that of birth. The dotted lines Am are projected health curves in the absence of challenge, and slope upwards because of normal gains with maturity. Episode $D$ terminates in a permanent decrement in health, $g 3$, and the series D-F represents increases in vulnerability due to successive challenges, ending in death. (b) Pre- and postnatal immunological health can be absolutely measured as shown in antibody levels, ${ }^{7}$ but physiological and mental health also influence coping with and outcome of infections. Although each type of health may be charted separately, all types are of course linked in the individual. For example, consider the series: social health (work stress through personal relationships) - psychological health (feelings of failure)-physiological health and physical signs (structural organ changes: ulcer, degenerative changes, emphysema).

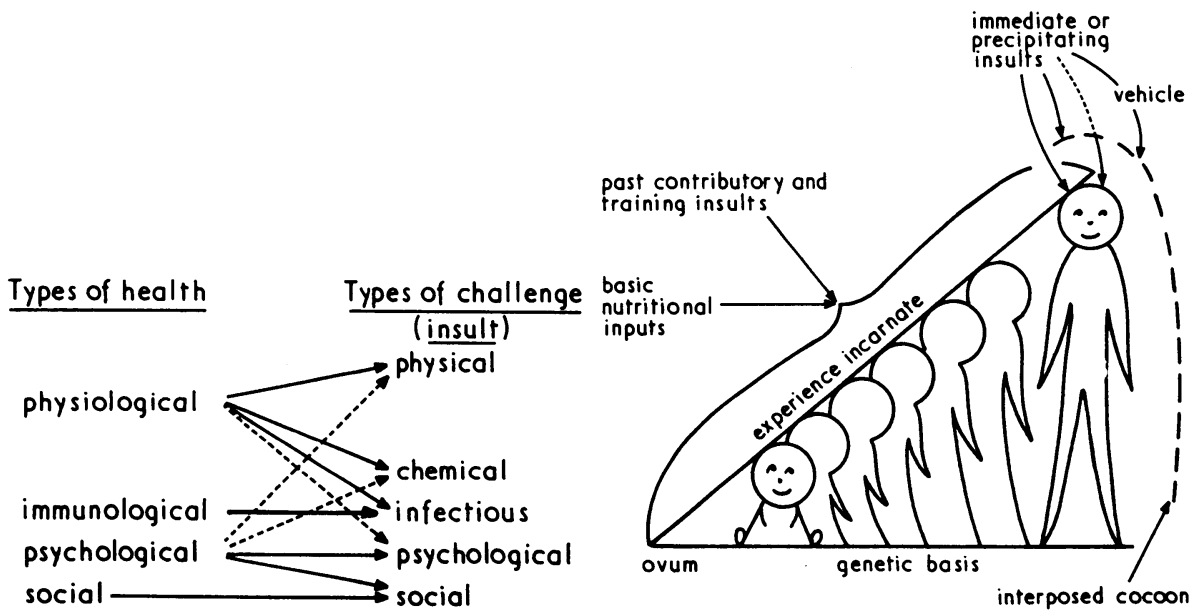

FIG. 2-Types of health in relation to types of challenge. FIG. 3-Operation of challenges in multiple causation of diseases. The health of the individual from ovum on is decided by challenges or insults (whether damaging or training) interacting with his genetic base. The self may thus be described in Dubos's ${ }^{8}$ term as "experience incarnate." Superimposition of an immediate or precipitating insult may "cause" disease; but all diseases are to some degree multicausational. Although these insults may be essential (only the tubercle bacillus can cause tuberculosis), they may not be obligatory or inevitably causative (exposure to the tubercle bacillus usually does not result in tuberculosis). These insults may be received directly or may be delivered by vehicles: water, an infected individual, an insect vector, or an intermediate host may deliver an infectious organism and cigarettes may deliver carcinogens. The dotted line indicates precipitating insults arising from within an otherwise protective cocoon.

disease (fig. 1 $a, \mathrm{C}-\mathrm{F}$ ). During coping, vulnerability to other insults is increased and there may be sequences that progressively lower health (fig. 1a, E-F). But the body and the person learn something and the level of health usually rises after coping (fig. 1a, $\left.\mathrm{g}_{1}, \mathrm{~g}_{2}\right)$. These rises account for most of a person's health and stamina. Mechanisms of coping reflect several types of health (fig. 2; see also fig. $1 b$ ).

Obversely, health may also be measured by the amount of protection from insults required to maintain a person's normal curve of health. Protective cocoons (fig. 3) range from the uterus to family, housing, and social institutions. There is constant feedback between individual and cocoons, and challenges may arise from within what is supposed to be a protective cocoon.

This definition of health in terms of a system can also be applied to groups such as family, community, and society: we can conceive that such a group, taken as an entity, enjoys societal health analogous to the social health of an individual. ${ }^{6}$ Because all efforts at creating societies have required a frustrating limitation of potentialities and fettering of minds, many who feel entrapped by this process swell the number of "deviates," some of whom could, through their perceptiveness, help to remedy societal defects. The relations between the health of the individual and the societal health of his milieu demand further study.

This view of health provides a conceptual basis for attempts to measure health, indicates that there are distinct types of health, encourages an attitude that facilitates planning for health, emphasizes that coping trains but may render vulnerable, draws attention to sets of cocoons in the milieu, and, by application to the societal health of cocoons, enhances the study of social structures by sociologists and cultural anthropologists as well as by health professionals.

\section{J. RALPH AUDY}

G. W. Hooper Foundation for Medical Research chool of Medicine,

Saniversity of Calif

Audy, J. R., Medical Times, 1973, 101, no. 7

Symposium, International fournal of Epidemiology, 1972, 1, 319. Grogono, A. W., International fournal of
Epidemiology, 1973, 2, 5.

Grogono, A. W., and Woodgate, D. J., Lancet, 1971, 2, 1024.

Audy, J. R., in Environ/Mental. Essays on the Planet as a Home, ed. P. Shepard and D. McKinley, p. 140. Boston and New York, Houghton Mifflin, 1971.

6 Audy, J. R., and Dunn, F. L., in Human Ecology, ed. F. Sargent, jun., chaps. 15, 16 , pp. 325, 345. Amsterdam, North-Holland, 1973. Allansmith, M., in Human Development, ed. F Falkner, p.

8 Dubos, R., Mirage of Héalth. Utopias, Progress and Biological Change, 1st edn., p. 233. New York, Harper, 1959.

\section{Formylation of Folate}

SIR,-We note with interest the reply of Drs. Janet Perry and I. Chanarin (29 September, p. 698) to our suggestions (15 September, p. 591) regarding their paper (9 June, p. 588).

In an experiment in this department six jejunal sacs from three animals were incubated, as described elsewhere, ${ }^{1}$ for an hour in phosphate-Ringer solutions containing added glucose. The resulting concentrations of folate in the serosal and mucosal solutions, as indicated by microbiological assay, are given below (in $\mathrm{ng} / \mathrm{ml} \pm$ S.E.M.).

\begin{tabular}{|c|c|c|c|}
\hline Solution & Total Folate & $\begin{array}{c}\text { Pediococcus } \\
\text { cerevisiae }\end{array}$ & $\begin{array}{l}\text { Streptococcus } \\
\text { faecalis }\end{array}$ \\
\hline $\begin{array}{l}\text { Serosal } \\
\text { Mucosal }\end{array}$ & $\begin{array}{r}24.3 \pm 2.0 \\
3.7 \pm 0.3\end{array}$ & $\begin{array}{l}5.1 \pm 0.6 \\
0.6 \pm 0.05\end{array}$ & $\begin{array}{l}8.3 \pm 1.2 \\
1.4 \pm 0.05\end{array}$ \\
\hline
\end{tabular}

Though these serosal concentrations are several times higher than those applied by Drs. Perry and Chanarin in their experiments, they are consistent with the intrinsic folate levels $(2.16 \mu \mathrm{g} / \mathrm{g})$ reported for rat intestinal tissue by Sotobayashi et al. ${ }^{2}$

Other recent publications confirm the importance of intrinsic folates in these investigations ${ }^{3}$ and indicate that folate transport in rat intestine proceeds independently of metabolism. ${ }^{34}$ We suggest, therefore, that despite their failure to record more than trace amounts of folate in their control solutions, Drs. Perry and Chanarin might usefully reconsider their conclusions in the light of our results.-We are, etc.,

JOHN A. BLAIR

I. T. JOHNSON J. R. G. BEAVON K. RATANASTHIEN

Department of Chemistry,

University of Aston in Birmingham,

Birmingham

1 Blair, J. A., Johnson, I. T., and Matty, A. J., Fournal of Physiology. In press.
Sotobayashi, H. Rosen, F., and Nichol, C. A., Sotobayashi, H., Rosen, 38.

Selhub, J., Brir, H., and Grossowicz, N. European fournal of Biochemistry, 1973, 33,

4 Olinger, E. J., Bertino, J. R., and Binder, H. J. Fournal of Clinical Investigation, 1973, 52, 2138 .

\section{Loud Knocking on the Back Door}

SIR,-Your correspondent Mr. John Squire (20 October, p. 172) objects to space being given to a consultant surgeon who advertised 